\title{
UJI EKSTRAK ETANOL 70\% DAUN SIRIH (Piper betle L.) TERHADAP BLEEDING TIME PADA MENCIT JANTAN GALUR SWISS WEBSTER
}

\author{
THE EFFECT OF THE 70\% ETHANOL EXTRACT OF BETEL LEAF (PIPER BETLE \\ L.) ON BLEEDING TIME IN MICE SWISS WEBSTER STRAIN
}

\author{
Tri Sutopo, Rochmadina Suci Bestari, Retno Sintowati \\ Fakultas Kedokteran Universitas Muhammadiyah Surakarta \\ Korespondensi, dr. Rochmadina Suci Bestari, Email:rsb156@ums.ac.id
}

\begin{abstract}
ABSTRAK
Tanaman sirih (Piper betle L.) mengandung tanin dan flavonoid yang diduga memiliki efek sebagai agen hemostatik/penghentian perdarahan. Penelitian ini bersifat experimental laboratorium dengan metode Post Test Only With Control Group Design. Hewan uji yang digunakan adalah 25 ekor mencit jantan galur Swiss Webster yang dibagi menjadi Kelompok Kontrol Negatif diberikan aquades steril, Kelompok kontrol positif diberikan epinefrin 1:1000, Kelompok perlakuan pertama diberikan ekstrak etanol daun sirih konsentrasi 10\%, Kelompok Perlakuan kedua konsentrasi 20\%, dan Kelompok perlakuan ketiga konsentrasi 40\%. Masing-masing kelompok dihitung bleeding time dengan menggunakan metode Duke. Hasil penelitian menunjukkan ekstrak etanol daun sirih konsentrasi 10\%, 20\%, dan 40\% dapat memperpendek bleeding time dengan rerata waktu penghentian perdarahan secara berturut-turut adalah 124,60 detik, 104,80 detik, dan 92,60 detik. Analisis data one-way ANOVA menunjukkan rerata yang berbeda secara bermakna terhadap bleeding time pada kelima kelompok setelah diberikan perlakuan dengan $p=0,000(p<0,05)$. Kesimpulan : Ekstrak etanol 70\% daun sirih (Piper betle L.) konsentrasi 10\%, 20\%, dan 40\% dapat memperpendek bleeding time pada mencit jantan galur Swiss Webster.
\end{abstract}

Kata Kunci : Ekstrak etanol, daun sirih (Piper betle L.), bleeding time

\section{ABSTRACT}

Betel plant (Piper betle L.) contains tannins and flavonoids that is considered to have effect as a hemostatic agent/cessation of bleeding. This study was experimental laboratory research with Post Test Only With Control Group Design. The animals used in this research were 25 male Swiss Webster mice. They were divided into 5 groups. The negative control group was given sterile distilled water, Positive Control group was given epinephrine 1:1000, the first, second and third treatment group was given ethanol extract of betel leaf with concentration of $10 \%, 20 \%$, and $40 \%$ respectively. The bleeding time of each group was calculated by using Duke method. The data was analyzed by applying one-way ANOVA test and LSD (Least Significant Difference) test. The results shows ethanol extract of betel leaf with concentration of $10 \%, 20 \%$, and $40 \%$ can decrease bleeding time with mean value of bleeding termination time as follows 124.60 seconds, 104.80 seconds and 92.60 seconds. One-way ANOVA test shows that there were significant difference mean of bleeding time in the five groups after given treatment with $p=$ $0.000(p<0.05)$. Thus, it is concluded that the ethanol extract $70 \%$ of betel leaf (Piper betle L.) at concentration of $10 \%, 20 \%$, and $40 \%$ could decrease bleeding time in male Swiss Webster mice.

Keywords: ethanol extract of betel leaf (Piper betle L.), bleeding time

\section{PENDAHULUAN}

Organisasi kesehatan dunia atau WHO mendukungupaya peningkatan keamanan dan khasiat dari obat tradisional.WHO merekomendasikan penggunaan obat tradisional untuk pemeliharaan kesejahteraan masyarakat, pencegahan dan pengobatan penyakit, terutama untuk penyakit kronis dan penyakit degeneratif (WHO, 2003).

Penggunaan bahan alam sebagai obat tradisional di Indonesia telah dilakukan oleh nenek moyang kita sejak berabad-abad yang lalu, 
sebelum obat modern ditemukan dan dipasarkan. Hal itu tercermin antara lain pada lukisan di relief Candi Borobudur dan resep tanaman obat yang ditulis dari tahun 991 sampai 1016 pada daun lontar di Bali (Dewoto, 2007). Indonesia yang beriklim tropis merupakan negara dengan keanekaragaman hayati yangcukup luas. Dari 40.000 jenis flora yang tumbuh di dunia, 30.000 diantaranya tumbuh di Indonesia dan sekurangkurangnya 9.600 spesies diketahui berkhasiat obat, tetapi baru 300 spesies yang dimanfaatkan sebagai industri obat tradisional dan sebagai bahan baku obat tradisional (Depkes RI, 2007).

Salah satu tanaman obat di Indonesia yang dapat dimanfaatkan sebagai obat tradisional adalah sirih (Piper betle L.).Secara tradisional sirih dimanfaatkan sebagai obat sariawan, sakit tenggorokan, obat batuk, obat cuci mata, obat keputihan, menghentikan pendarahan pada hidung / mimisan, mempercepat penyembuhan luka, menghilangkan bau mulut. Secara farmakologi daun sirih memiliki sifat styptic (menahan perdarahan), stomachic (obat saluran pencernaan), vulnerary (menyembuhkan luka kulit), astringen, diuretik, dan anti peradangan (Moeljanto \& Mulyono, 2003).

Perdarahan luar adalah perdarahan yang berasal dari luka terbuka sehingga dapat dilihat dari pemeriksaan fisik (Thygerson, 2012).Mekanisme hemostatik bawaan tubuh secara normal sudah memadai untuk memperbaiki kerusakan dan menghentikan pengeluaran darah dari pembuluh mikrosirkulasi halus ini.Mekanisme tubuh dalam menghentikan perdarahaan melibatkan tiga langkah utama : (1) spasme vaskuler,(2) pembentukan sumbatan trombosit, dan (3) koagulasi darah (pembentukan bekuan darah) (Sherwood, 2015).Mekanisme-mekanisme tersebut dapat dipercepat dengan cara pemberian perlakuan tertentu. Salah satu perlakuan tersebut adalah pemberian topikal daun Sirih (Piper betle L.)(Wijayanto, 2005).

Hasil pemeriksaan penapisan fitokimia ekstrak etanol daun sirih mengandung tanin, antrakuinon, flavonoid, alkaloid,terpenoid, saponin, glikosida, gula, dan phlobatannin (Kumari dan Nirmala, 2015). Senyawa utama yang berperan dalam proses pembekuan darah adalah tannin dan flavonoid (Rahayuet al.,
2011). Tannin merupakan senyawa kimia yang kompleks, terdiri dari beberapa polifenol, dengan konsentrasi tertinggi ditemukan hampir setiap bagian dari tumbuhan, seperti daun, batang, akar, buah, dan biji (Khanbabaee \&Teunis,2001). Tannin bersifat astringen yang memiliki kemampuan untuk membentuk kompleks dengan makromolekul, terutama protein.Kemampuan tersebut dapat mempercepat proses pembekuan darah(Hassanpouret al., 2011).

Dalam tumbuhan, flavonoid umumnya merupakan pigmen-pigmen yang tersebar luas dalam bentuk senyawa glikon dan aglikon dan dapat menghambat perdarahan (Narayana et al., 2001). Mekanisme lain dari flavonoid dalam penghentian perdarahan adalah dengan mekanisme vasokonstriksi (Dougnonet al., 2012).

Penelitian sebelumnya yang dilakukan oleh Wijayanto (2005) menunjukkan bahwa ekstrak daun sirih memiliki aktivitas sebagai agen hemostatik / penghenti perdarahan pada mencit. Selain itu telah diteliti ekstrak etil asetat dan etanol daun sirih (Piper betle L.) dapat memperpendek waktu perdarahan pada mencit, dengan efektifitas yang sama (Tedjasulaksana, 2013). Penelitian yang dilakukan oleh Nilugal et al., 2014 didapatkan hasil bahwa pemberian salep daun sirih dan batang sirih memiliki kemampuan potensial dalam penyembuhan luka pada tikus putih (Wistar) (Nilugal et al.,2014).

\section{METODE}

Penelitian ini bersifat experimental laboratoriumdenganrancangan penelitian Post Test Only With ControlGroup Design. Penelitian dilaksanakan di Laboratorium Farmakologi Fakultas Kedokteran Universitas Muhammadiyah Surakarta pada bulan November 2015. Subjek yang digunakan dalam penelitian ini adalah ekstrak etanol daun sirih. Obyek penelitian yaitu mencit jantan galur Swiss Webster yang dipilih secara purposive sampling dengan syarat usia kurang lebih 2-3 bulan dengan berat badan kirakira 20-30 gram. Mencit dipilih secara simple random.Penentuan besar sampel setiap kelompok ditentukan berdasarkan rumus perhitungan Federer yang diperoleh hasil minimal 5 ekor mencit perkelompok (5 kelompok). Sehingga jumlah keseluruhan sampel yang akan digunakan 
sebanyak 25 ekor mencit jantan. Dalam penelitian 5 kelompok tersebut diberikan perlakuan yaitu kelompok kontrol negatif diberikan aquades steril, kelompok kontrol positif diberikan epinefrin 1:1000, kelompok perlakuan pertama diberikan ekstrak etanol daun sirih konsentrasi 10\% (10 gram ekstrak etanol daun sirih ditambah dengan $100 \mathrm{ml}$ aquades steril), kelompok perlakuan kedua diberikan ekstrak etanol daun sirih konsentrasi 20\% (20 gram ekstrak etanol daun sirih ditambah dengan $100 \mathrm{ml}$ aquades steril), dan kelompok perlakuan ketiga diberikan ekstrak etanol daun sirih konsentrasi 40\% (40 gram ekstrak etanol daun sirih ditambah dengan $100 \mathrm{ml}$ aquades steril). Identifikasi variabel terdiri dari variabel bebas: dosis ekstrak etanol daun sirih (Piper betle L.) (skala rasio), variabel terikat:bleeding time(skala rasio). Alat yang digunakan : alat maserasi, alat timbang, blender, alat pengaduk, penggaris, spidol, kandang hewan uji, minor surgery (scalpel), kertas saring, stop watch, alat pencukur rambut. Bahan yang digunakan : bahan utama berupa daun sirih (piper betle L.), makanan dan minuman hewan uji (pelet dan air putih), epinefrin, akuades steril, ethyl chlorida.

\section{Cara Kerja :}

Langkah 1: Pembuatan ekstrak etanol $70 \%$ daun sirih dilakukan dengan cara maserasi, yaitu daun sirih segar dicuci bersih dan diiris halus, kemudian dikeringkan ditempat teduh. Bahan yang telah kering kemudian dihaluskan menggunakan blender hingga berbentuk serbuk. Serbuk yang telah didapatkan kemudian direndam (dimaserasi) selama 3 hari dalam 1liter pelarut etanol $70 \%$. Setelah 3 hari, dilakukan penyaringan dengan kertas saring sehingga didapatkan filtrat yang diuapkan pelarutnya dengan mengunakan rotary vacuum evaporatour dengan suhu $50^{\circ} \mathrm{C}$. Pada akhir proses ini didapatkan ekstrak etanol daun sirih yang berwarna kehijauan. Hasil ekstrak ini yang digunakan sebagai bahan uji.

Langkah 2: Mencit yang telah memenuhi kriteria diberi perlukaan dengan cara ekor mencit diberi tanda sepanjang $2 \mathrm{~cm}$ dari ujung ekor. Rambut pada ekor dibersihkan menggunakan alat pencukur rambut kemudian dibersihkan menggunakan etanol 70\%, dianestesi secara topikal menggunakan ethyl chlorida di sekitar ekor yang akan dilukai,kemudian diberi perlukaan sepanjang $3 \mathrm{~mm}$ menggunakan minor surgery. Darah yang keluar diserap menggunakan kertas saring setiap 15 detik tanpa menyentuh permukaan luka. Waktu mulai diukur menggunakan stop watch ketika darah terserap pertama kali sampai darah berhenti dengan ditunjukkan tidak ada lagi darah yang terserap pada kertas saring. Interval waktu saat darah keluar pertamakali hingga darah berhenti keluar adalah waktu perdarahan/ bleeding time.

Langkah 3 :Pembagian kelompok dan perlakuan pada hewan coba. Pertama mencitdibagi secara acak dalam 5 kelompok, masing-masing keompok terdiri dari 5 ekor mencit : kelompok I sebagai kontrol negatif (aquades steril), kelompok II kontrol positif (epiefrin), kelompok III sebagai kelompok perlakuan I (ekstrak daun sirih konsentrasi 10\%), kelompok IV sebagai kelompok perlakuan II (ekstrak daun sirih konsentrasi 20\%), dan kelompok $\mathrm{V}$ sebagai kelompok perlakuan III (ekstrak daun sirih ekstrak konsentrasi 40\%). Semua hewan uji diadaptasikan selama 3 hari dalam lingkungan laboratorium.Hari berikutnya mencit diberi perlukaan sesuai prosedur.Setelah diberi perlukaan, ekor mencit dicelupkan kedalam masing-masing kelompok selama 5 detik.

Langkah 4 :Masing-masing kelompok dihitung waktu perdarahan/bleeding time dengan menggunakan metode Duke. Data yang diperoleh dianalisis dengan uji statistik one-wayANOVAdan uji statistik LSD (Least Significant Difference).

\section{HASIL DAN PEMBAHASAN}

\section{Determinasi Tanaman}

Determinasi tanaman dilakukan untuk identifikasi tanaman sehingga menghindari kesalahan dalam pengambilan tanaman. Determinasi tanaman dilakukan di Laboratorium Biologi Fakultas Keguruan dan Ilmu Pendidikan (FKIP) Universitas Muhammadiyah Surakarta.

Hasil determinasi tanaman sirih adalah sebagai berikut:

1b, 2b, 3b, 4b, 13b, 14b, 17b, 18b, 19b, 20b, 21b, 22b, 23b, 24b, 25b, 26b, 27b, 799b, 800b, 801b, 802 b, 806b, 807b, 809b, 810b, 811a, 812b, 815b, $816 \mathrm{~b}, 818 \mathrm{a}$, 
$819 b, \ldots$

$1 b, 2 b, 3 b, \ldots$.

$1 b, 3 a, 4 b, 6 b, 7 b, 8 b, 9 b, 23 b, \ldots$ $\rightarrow$ Familia : Piperaceae

$\rightarrow$ Genus : Piper

$\rightarrow$ Spesies :Piper betle L.

\section{Randemen}

Randemen ekstrak digunakan untuk membandingkan antara ekstrak dengan simplisia (daun sirih). Didapatkan hasil 1 gram daun sirih kering mengandung 0,105 gram ekstrak kental.

\section{Hasil Pengukuran Berat Badan Mencit}

Tabel 1. Rata-Rata Berat Badan Mencit

\begin{tabular}{llc}
\hline No & \multicolumn{1}{c}{ Kelompok } & Rerata Berat Badan $($ gram) \pm SD \\
\hline 1. & Kontrol Negatif & $22.40 \pm 2.966$ \\
2. & Kontrol Positif & $24.00 \pm 3.742$ \\
3. & Perlakuan 1 & $23.20 \pm 2.280$ \\
4. & Perlakuan 2 & $23.00 \pm 1.581$ \\
5. & Perlakuan 3 & \pm .894 \\
\hline
\end{tabular}

Sumber : Data Primer, 2015

\section{Hasil Uji Efek Ekstrak Terhadap Bleeding Time}

Tabel 2. Bleeding Time Pada Mencit Dari Masing-Masing Kelompok Perlakuan

\begin{tabular}{cccccc}
\hline Kampel & KN (detik) & KP (detik) & P1 (detik) & P2 (detik) & P3 (detik) \\
\hline 1 & 165 & 68 & 105 & 95 & 88 \\
2 & 207 & 78 & 125 & 104 & 93 \\
3 & 165 & 89 & 175 & 95 & 91 \\
4 & 198 & 77 & 100 & 112 & 93 \\
5 & 194 & 78 & 118 & 118 & 98 \\
\hline Mean \pm SD & $185.80 \pm 19.563$ & $78.00 \pm 7.450$ & $124.60 \pm 29.888$ & $104.80 \pm 10.232$ & $92.60 \pm 3.647$
\end{tabular}

Sumber : Data Primer, 2015

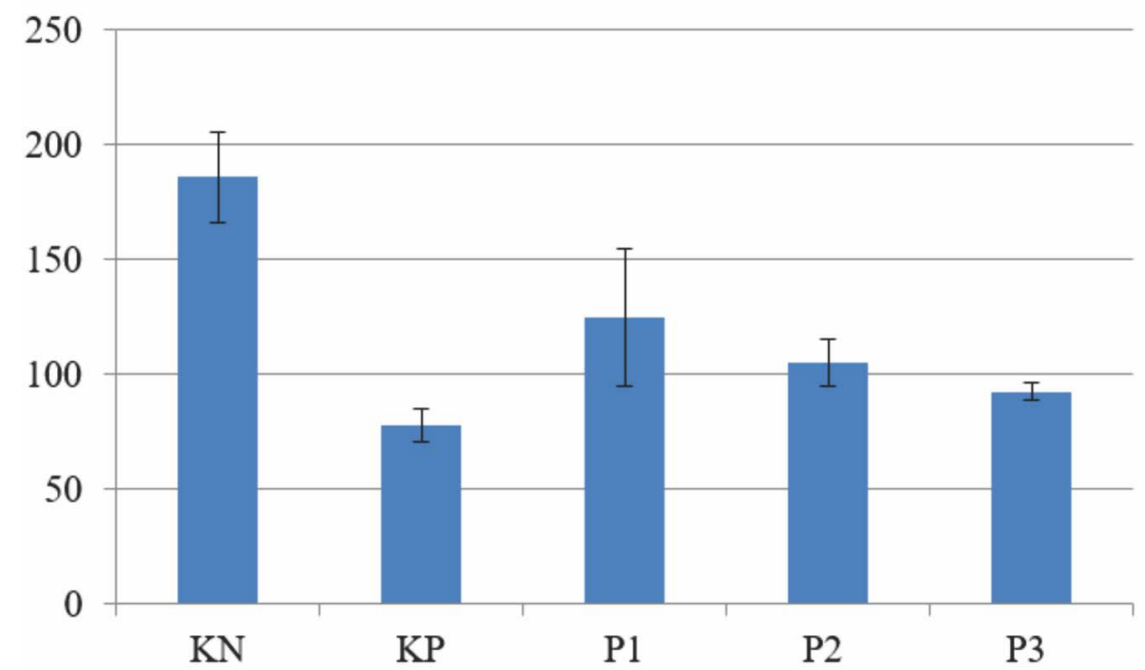

Gambar 1 : Grafik Rerata Bleeding Time Tiap Kelompok Perlakuan 
Keterangan :

$\mathrm{KN}=$ Kelompok kontrol negatif (pemberian aquades)

$\mathrm{KP}=$ Kelompok kontrol positif (pemberian epinefrin)

$\mathrm{P} 1=$ Kelompok perlakuan dengan pemberian ekstrak daun sirih 10\%

P2 = Kelompok perlakuan dengan pemberian ekstrak daun sirih 20\%

P3 = Kelompok perlakuan dengan pemberian ekstrak daun sirih 40\%

\section{Hasil Analisis Statistik}

1. Hasil Uji Distribusi Data

Uji distribusi data menggunakan Uji Saphiro-Wilk, uji tersebut digunakan untuk mengetahui distribusi data kelompok yang kurang dari 50 sampel. Hasil analisis Saphiro-Wilk didapatkan nilai $\mathrm{p}=0,096$ ( $p>0,05)$. Maka disimpulkan bahwa data berdistribusi normal.

2. Hasil Uji Test of Homogenecity of Varians

Uji homogenitas varian dilakukan dengan menggunakan uji statistik Levene Test of Varians. Hasil dari uji ini didapatkan nilai $\mathrm{p}=0,218(\mathrm{p}>0,05)$ yang menunjukkan data adalah homogen.
3. Hasil Uji one way ANOVA

Pada analisis data menggunakan uji one way ANOVA didapatkan hasil nilai $\mathrm{P}=0,000$. Nilai probabilitas merupakan parameter untuk mengambilkeputusan.Dari hasil uji one way ANOVA menunjukkan hasil nilai probabilitas $<0,05$ maka dalam penelitian ini ekstrak etanol $70 \%$ daun sirih (Piper betle L.) mampu mempengaruhi waktu penghentian perdarahan (bleeding time) pada hewan uji.

4. Hasil Uji Least Significant Difference $(L S D)$

Tabel 3. Uji Post Hoc Least Significant Difference (LSD)

\begin{tabular}{lll}
\hline \multicolumn{1}{c}{ Kelompok } & \multicolumn{1}{c}{ Nilai "P" } & \multicolumn{1}{c}{ Keterangan } \\
\hline $\mathrm{KN}-\mathrm{KP}$ & 0,000 & Berbeda signifikan \\
$\mathrm{KN}-\mathrm{P} 1$ & 0,000 & Berbeda signifikan \\
$\mathrm{KN}-\mathrm{P} 2$ & 0,000 & Berbeda signifikan \\
$\mathrm{KN}-\mathrm{P} 3$ & 0,000 & Berbeda signifikan \\
$\mathrm{KP}-\mathrm{P} 1$ & 0,000 & Berbeda signifikan \\
$\mathrm{KP}-\mathrm{P} 2$ & 0,000 & Berbeda signifikan \\
$\mathrm{KP}-\mathrm{P} 3$ & 0,015 & Berbeda signifikan \\
$\mathrm{P} 1-\mathrm{P} 2$ & 0,066 & Tidak berbeda signifikan \\
$\mathrm{P} 1-\mathrm{P} 3$ & 0,002 & Berbeda signifikan \\
$\mathrm{P} 2-\mathrm{P} 3$ & 0,112 & Tidak berbeda signifikan \\
\hline
\end{tabular}

Penelitian yang dilakukan di laboratorium Farmakologi Universitas Muhammadiyah Surakarta ini bertujuan untuk mengetahui ada tidaknya efek ekstrak etanol $70 \%$ daun sirih (Piper betle L.) terhadapbleeding time pada mencit jantan galur swiss webster. Penelitian ini menggunakan 5 kelompok, setiap kelompok terdiri atas 5 mencit. Dari lima kelompok tersebut terbagi menjadi kelompok I sebagai kontrol negatif (aquades), kelompok II sebagai kontrol positif (epinefrin 1:1000), kelompok III sebagai kelompok perlakuan 1 (P1) dengan diberikanekstrak etanol $70 \%$ daun sirih (Piper betle L.) konsentrasi $10 \%$, kelompok IV sebagai kelompok perlakuan 2 (P2) diberikan ekstrak etanol $70 \%$ daun sirih (Piper betleL.) konsentrasi 20\%, dan kelompok V sebagai kelompok perlakuan III (P3) diberikan ekstrak etanol $70 \%$ daun sirih (Piper betle L.) 
konsentrasi $40 \%$. Hewan yang telah terdistribusi dalam masing-masing kelompok kemudian diberi perlukaan guna mengetahui waktu perdarahan (bleeding time).

Bleeding time merupakan waktu mulai perdarahan pada mencit sampai darah mencit berhenti keluar, yaitu ketika tidak ada noda darah pada kertas saring. Data yang diperoleh dari penelitian kemudian dilakukan uji statistik dengan menggunakan program SPSS guna mengetahui nilai probabilitas efek ekstrak etanol $70 \%$ daun sirih (Piper betle L.) terhadapbleeding time pada mencit jantan galur Swiss Webster.

Pada analisis data menggunakan uji one way ANOVA didapatkan hasil nilai $\mathrm{P}=0,000(\mathrm{p}<0,05)$ sehingga disimpulkan terdapat perbedaan waktu penghentian perdarahan (bleeding time) yang signifikan antar kelompok hewan ujii. Dari hasil uji one way ANOVA dapat ditentukan bahwa hipotesis H1 peneliti diterima. Maka ekstrak etanol 70\% daun sirih (Piper betle L.) mampu mempengaruhi waktu penghentian perdarahan (bleeding time) pada hewan uji. Hal ini karena terdapat beberapa senyawa dalam daun sirih yang berfungsi sebagai agen hemostasis. Beberapa senyawa tersebut adalah tanin dan flavonoid. Mekanisme tanin dalam menghentikan perdarahan yaitu melalui efek astringentnya (Klatoe et al., 2012). Sedangkan flavonoid dapat menghentikan perdarahan dengan mekanisme vasokonstriksi pada pembuluh darah (Dougnon et al., 2012).

Pada hasil uji post hoc dengan menggunakan uji Least Significant Difference(LSD), antara kelompok kontrol negatif dengan kelompok kontrol positif didapatkan perbedaan yang signifikan $(p<0,05)$. Hal tersebut menunjukkan bahwa pemberian epinefrin sebagai kontrol positif mempunyai efek penghentian perdarahan lebih cepat dibandingkan dengan kontrol negatif yang hanya diberi aquades. Hal ini dikarenakan sifat dari kontrol negatif (aquades) adalah netral, sehingga tidak akan memberikan efek terhadap proses penghentian perdarahan (hemostasis) pada hewan uji. Sedangkan penggunaan epinefrin sebagai kontrol positif memiliki efek vasokontriksi pada pembuluh darah dan mempercepat pembentukan bekuan darah, sehingga hal ini akan mempengaruhi kecepatan waktu penghentian perdarahan (Shoroghi et al., 2008).
Antara kelompok kontrol negatif dengan kelompok perlakuan (P) 1, 2 dan 3 didapatkan adanya perbedaan yang signifikan $(\mathrm{p}<0,05)$. Hal tersebut menunjukkan bahwa pemberian ekstrak etanol $70 \%$ daun sirih pada konsentrasi 10\%, 20\%, dan $40 \%$ mempunyai efek penghentian perdarahan lebih cepat dibandingkan dengan kontrol negatif yang hanya diberi aquades.

Hasilanalisis Post Hoc denganmenggunakan uji Least Significant Difference(LSD). antara kelompok kontrol positif dengan kelompok perlakuan (P) 1, 2 dan 3 didapatkan perbedaan yang signifikan $(p<0,05)$. Hal tersebut menunjukkan bahwa kelompok kontrol positif mempunyai efek penghentian perdarahan lebih cepat dibandingkan dengan kelompok perlakuan (P) 1, 2, dan 3 yang di berikan ekstrak etanol $70 \%$ daun sirih konsentrasi $10 \%, 20 \%$, dan $40 \%$.

Antarakelompokperlakuandidapatkanhasil, P1 (konsentrasi 10\%) terhadap P2 (konsentrasi $20 \%)$ tidak berbeda signifikan $(p>0,05)$. Hal tersebut menunjukkan kelompok P1 dengan kelompok P2 mempunyai efek menghentikan perdarahan yang sebanding, meskipun rata-rata waktu menghentikan perdarahan kelompok P2 lebih cepat dari rata-rata waktu kelompok P1 dalam menghentikan perdarahan (tabel 2). Pada kelompok perlakuan P1 terhadap P3, didapatkan perbedaan yang signifikan $(\mathrm{p}<0,05)$. Hal tersebut menunjukkan bahwa kelompok P3 (konsentrasi $40 \%$ ) mempunyai efek penghentian perdarahan lebih cepatdibandingkan kelompok P1 (konsentrasi $10 \%)$. Hal ini dapat dilihat pada rata-rata waktu yang dibutuhkan oleh setiap kelompok perlakuan dalam menghentikan perdarahan. Kelompok P3 dengan konsentrasi pemberian ekstrak daun sirih sebesar $40 \%$ memiliki rata-rata waktu sebesar 92,60 detik. Sedangkan kelompok P1 124,60 detik. Dengan didapatkannya hasil tersebut, maka kelompok perlakuan P3 (konsentrasi 40\%) memiliki kemampuan yang lebih singkat dalam menghentikan perdarahan. Sedangkan antara kelompok perlakuan P2 terhadap P3 didapatkan perbedaan yang tidak signifikan $(p>0,05)$. Hal tersebut menunjukkan kelompok $\mathrm{P} 2$ dengan kelompok P3 mempunyai efek menghentikan perdarahan yang sebanding, meskipun rata-rata waktu menghentikan perdarahan kelompok P3 lebih cepat dari rata-rata waktu kelompok P2 dalam menghentikan perdarahan (tabel 2) 
Hasil yang diperoleh dari uji statistik menunjukkan bahwa pemberian ekstrak etanol 70\% daun sirih (Piper betle L.) dapat mempengaruhi waktu perdarahan (bleeding time) pada mencit walaupun belum dapat menandingi kekuatan epinefrin sebagai agen hemostatik. Hal ini menunjukkan bahwa kandungan tanin dan flavonoid dalam dalam daun sirih (Piper betle L.) dapat mempengaruhi waktu perdarahan (bleeding time). Flavonoid serta tanin yang dikandung dalam daun sirih diduga berperan dalam penghambatan sintesis lokal dan produksi dari prostaglandin $\mathrm{I}_{2}$ vasodilatasi (prostasiklin) sehingga menyebabkan proses kontraksi luka (vasokonstriksi) menjadi lebih cepat (Bunting et al., 1976 cit Salawu et al., 2008).Tanin merupakan salah satu komponen yang bertanggungjawab terhadap sekresi 5-hydroxytryptamin (serotonin) dan thromboxane A2 (Rohrbach, 2007 cit Sari et al., 2013).

Serotonin dan thromboxane A2 merupakan senyawa yang disekresi akibat adanya respon terhadap aktivasi trombosit yang melekat pada dinding pembuluh darah yang rusak. Serotonin memiliki fungsi sebagai vasokonstriktor kuat, sedangkan thromboxane A2 selain juga berfungsi sebagai vasokonstriktor, berperan dalam proses aktivasi trombosit yang berdekatan dan karena sifat lengket dari trombosit tambahan ini, maka akan menyebabkannya melekat pada trombosit yang semula sudah aktif (agregasi trombosit). Siklus aktivasi trombosit ini berlangsung terus,menyebabkan penarikan lebih banyak lagi trombosit tambahan hingga membentuk sumbat trombosit. Sumbat ini pada mulanya longgar, namun biasanya bisa berhasil menghalangi hilangnya darah bila luka di pembuluh darah kecil, tetapi bila lukanya besar, maka diperlukan mekanisme pembekuan darah untuk menghentikan perdarahan (Guyton, 2014 ;Ganong, 2003).

\section{SIMPULAN}

Kesimpulan dari hasil penelitian ini adalah sebagai berikut :

1. Pemberian ekstrak etanol $70 \%$ daun sirih (Piper betle L.) konsentrasi 10\%, 20\%, dan $40 \%$ dapat mempercepat waktu penghentian perdarahan (bleeding time) pada mencit jantan galur Swiss Webster.

2. Pemberian ekstrak etanol $70 \%$ daun sirih
(Piper betle L.) konsentrasi 20\%, dan 40\% memberikan efek yang maksimal dalam menghentikan perdarahan (bleeding time) pada mencit jantan galur Swiss Webster.

\section{DAFTAR PUSTAKA}

Departemen Kesehatan RI. 2007. Kebijakan Obat Tradisional Nasional Tahun 2007 http:// binfar.depkes.go.id(18 maret 2015)

Dewoto H.R. 2007. Pengembangan Obat Tradisional IndonesiaMenjadi Fitofarmaka. Majalah Kedokteran Indonesia vol 57 (7) : 205-11

DougnonT.V.,Tamègnon V.D., JeanR.K., Julien S., JeanM.A., AléodjrodoP.E., et al. 2012. In vitro Hemostatis Activity Screening of Sap of Jatropha Multifide L. (Euphorbiaceae) Used in Traditional Medicine at Cotonoun (Benin).Journal of Physiology and Pharmacology Advance vol 2(6) : 227-34

Ganong W.F. 2003. Buku Ajar Fisiologi Kedokteran. Jakarta : Penerbit Buku Kedokteran EGC

Guyton A.C, Hall J.E. 2014. Buku Ajar Fisiologi Kedokteran. Jakarta : Penerbit Buku Kedokteran EGC

HassanpourS., Naser M.S., Behrad E., Farhad B.M. 2011. Plants and secondary metabolites (Tannins).International Journal of Forest, Soil and Erosion (IJFSE) vol 1 (1) : 47-53

Khanbabaee K, Teunis V.R. 2001. Tannin : Clasification and Definition. The Royal Society of Chemistryvol $18: 641-49$

Klatoe J.R., Dougnon T.V., SacramentoT.I., Dandjesso C., Edorh A.P.,KoudokponH.,et al. 2012. Hemostatic potential of the sap of Musa sapientum L. (Musaceae).Journal of Applied Pharmaceutical Science vol 02 (06): 65-9

Kumari O.S, Nirmala B.R. 2015. Phyto Chemical Analysis Of Piper Betel Leaf Extract. World Journal of Pharmacy and Pharmaceutical Sciences (WJPPS) vol 4 (1) : 699-703

Moeljanto R.D, Mulyono. 2003. Khasiat dan Manfaat Daun Sirih Obat Mujarab dari Masa Ke masa. Jakarta : Agro Media 
Narayana K.R., Reddy M.S.,Chaluvadi M.R., Krishna D.R. 2001. Bioflavonoid Classification, Pharmacological, Biochemical Effect and Therapeutic Potential.Indian Journal of Pharmacology vol $33: 2-16$

Nilugal K.C., Komathi P., Ugander R.E., Asif I.C. 2014. Evaluation of Wound Healing Activity of Piper Betle Leaves and Stem Extract In Experimental Wistar Rats. American Journal of Pharmtech Research vol 4(3):443-52

RahayuS.T., Aprilita R.Y., Enda F. 2011. Uji Efek Hemostatik Ekstrak Etanol 96\% Herba Bandotan (Ageratum conyzoides L.) pada Tikus Putih (Rattus novergicus L.) Jantan Galur Sprague Dawley (SD). Farmasains vol $1: 203-207$

Salawu O.A., Aliyu M., Tijani A.Y. 2008. Haematological Studies on The Ethanolic Stem Bark Extract 0f Pterocarpus Erinaceus Poir (Fabaceae). African Journal of Biotechnology vol. 7 (9) :1212-15

Sari R.P., Sampurna., Danis P. 2013. Pengaruh Sari Buah Kurma (Phoenix dactylifera) terhadap Waktu Perdarahan. Sains Medika vol. 5 (1): $20-2$
Shoroghi M., SeyedH.S., Mahmood R., FarshidF., Mehrdad S., Mahmood S., et al. 2008. Effect of Different Epinephrine Concentrations on Local Bleeding and Hemodynamics during Dermatologic Surgery. Acta Dermatovenerol Croat vol 16(4):209-14

Sherwood L. 2015. Fisiologi Manusia, dari Sel ke Sistem. Jakarta : Buku Kedokteran EGC pp 430-431

Tedjasulaksana R. 2013. Ekstrak Etil Asetat dan Etanol Daun Sirih (Piper betle L.) Dapat Memperpendek Waktu Perdarahan Mencit (Mus Musculus). Jurnal Kesehatan Gigi vol 1(1):32-39

Thygerson A. 2012. First Aid Pertolongan Pertama.Jakarta: Penerbit Erlangga

WHO. 2003. Taditional Medicine. http://www. who.int/mediacentre/factsheets/fs 134/en/ (12 maret 2015)

Wijayanto T. 2005. Efek Pemberian Topical Daun Sirih (Piper betle L.) Terhadap Penghentian Perdarahan Eksterna Pada Mencit. Skripsi . Universitas Sebelas Maret 